\title{
Contemporary outcomes of catheter ablation of accessory pathways: complications and learning curve
}

\author{
Marek Jastrzębski ${ }^{1}$, Paweł Moskal ${ }^{1}$, Maciej Pitak ${ }^{2}$, Kamil Fijorek ${ }^{3}$, Andrzej Rudziński ${ }^{2}$, Danuta Czarnecka ${ }^{1}$ \\ ${ }^{1} 1^{\text {st }}$ Department of Cardiology, Interventional Electrocardiology and Hypertension, Jagiellonian University, Medical College, Krakow, Poland \\ ${ }^{2}$ Department of Cardiology, Institute of Paediatrics, Jagiellonian University Medical College, Krakow, Poland \\ ${ }^{3}$ Department of Statistics, Krakow University of Economics, Krakow, Poland
}

\begin{abstract}
Background and aim: The aim of this study was to examine contemporary results of accessory pathway (AP) ablation in a sizeable number of patients, focusing on periprocedural complications and the learning curve.

Methods: We performed a retrospective cohort study of consecutive AP ablation procedures at three centres by the same operator. In total 629 electrophysiological studies and 610 AP ablation procedures were performed in 570 patients (age: $33 \pm 18.9$ years).

Results: There was one $(0.16 \%)$ serious and there were $14(2.3 \%)$ minor periprocedural complications. Five hundred and ninety APs were successfully ablated: single/multiple procedure success was $93.4 \% / 96.7 \%$, while the average fluoroscopy time was $13.5 \mathrm{~min}$. There was significantly higher success and less fluoroscopy use with increased experience, while periprocedural complications seemed evenly distributed over the years. The learning was most pronounced for the first 120 cases. However, the learning curve fully flattened only after approximately 400 ablations.

Conclusions: This study suggests that in the modern era AP ablation is safer than it was in the first two decades after the introduction of catheter ablation of APs. Perhaps, in experienced centres there should be a lower threshold for referring asymptomatic/mildly symptomatic patients with pre-excitation for electrophysiological study.
\end{abstract}

Key words: accessory pathway, pre-excitation, ablation, complications, learning curve

Kardiol Pol 2017; 75, 8: 804-810

\section{INTRODUCTION}

Soon after the first catheter ablations of accessory pathways (AP) were reported in the 1980 s catheter-based ablation became a standard therapeutic approach in Wolff-Parkinson-White (WPW) syndrome [1, 2].

Indications for this procedure are based not only on the tachyarrhythmia-related symptoms and the risk of serious consequences of untreated $\mathrm{AP}$, but they also take into account the risks of the ablation procedure [3, 4]. The issue of serious complications of AP ablation is probably the most common reason for the failure to perform this usually curative procedure in asymptomatic or mildly symptomatic patients with overt pre-excitation. The efficacy and safety of AP ablation have been reported by several studies, albeit mainly in the previous century, soon after the introduction of this method [5-10]. Continuous fine-tuning of the ablation technique, better understanding of the electrophysiology and anatomy of the heart, and also technological advances (cryoablation, three-dimensional [3D] mapping systems) in the last decades could have influenced both the safety and success rates of this procedure. We believe that there is a scarcity of data concerning the outcomes of XXI-century AP ablation when performed by experienced operators.

The primary aim of this study was to examine contemporary periprocedural complications and the learning curve of AP ablation in a sizeable number of patients.

\section{Address for correspondence:}

Assoc. Prof. Marek Jastrzębski, MD, PhD, 1 $1^{\text {st }}$ Department of Cardiology and Interventional Electrocardiology, University Hospital, ul. Kopernika 17, $31-501$ Kraków, Poland, e-mail:mcjastrz@cyf-kr.edu.pl

Received: 11.01.2017 Accepted: 18.04.2017

Kardiologia Polska Copyright (C Polskie Towarzystwo Kardiologiczne 2017 


\section{METHODS}

We performed a retrospective cohort study of consecutive AP ablation procedures at three centres by the same operator (M.J.), from 2002 to mid-2016. For this, all ablation procedure descriptions, digital EP system records, hospital discharge notes, and pre- and post-procedural 12-lead electrocardiograms (ECG) of all patients scheduled for ablation were carefully reviewed. Pertinent clinical data such as age, gender, the presence of symptoms prior to ablation, occurrence of cardiac arrest/malignant atrial fibrillation (defined as need for emergency cardioversion or syncope/presyncope symptoms and ECG with shortest RR intervals $<250 \mathrm{~ms}$ ), were collected. The procedure-related following data were gathered: AP localisation (based on the stored fluoroscopic images of the catheter at the successful ablation site in anteroposterior and left anterior oblique views), ablation success/failure, and periprocedural complications. Successful procedure was defined as 1) complete elimination of AP conduction after a 30-min. waiting period; 2) lack inducibility of any atrioventricular (AV) re-entrant tachycardia, and 3) lack of recurrence of overt pre-excitation or tachycardia during the pre-discharge period of 24-48 h. Serious periprocedural complications were defined as: death, stroke, systemic embolism, second- and third-degree AV block or pacemaker implantation, tamponade, and any other life threatening event or the need for surgical intervention. Minor complications included bundle branch blocks, asymptomatic first-degree AV block, pericardial effusion treated conservatively, groin problems treated conservatively, and uncomplicated pneumothorax. Obtained data were later analysed by an independent biostatistician.

All procedures were performed with the same simplified three-catheter approach: 1) His bundle/right ventricular catheter, 2) coronary sinus (for left-sided APs) or right atrial (for right-sided and septal APs) catheter, and 3) radiofrequency ablation catheter (irrigated catheter for retrograde aortic access or coronary sinus/cardiac vein ablation and non-irrigated catheter for other APs/access routes). The following ablation settings were used: $35 \mathrm{~W} / 57^{\circ} \mathrm{C}$ for non-irrigated and $30 \mathrm{~W} / 43^{\circ} \mathrm{C}$ for irrigated catheters. For ablation in coronary sinus and cardiac veins, lower power (20-25 W) and shorter time (30 s instead of $1 \mathrm{~min}$ ) was used. Femoral vein, femoral artery and left subclavian vein access were used as considered appropriate. The only change in the ablation strategy during the 14-year study period was: 1) switch to routine placement of the coronary sinus catheter via femoral access from a previously used subclavian access after the first 210 cases (because of two pneumothoraces) and the introduction of a transseptal puncture for selected left-sided pathways (however, only when transaortic approach failed or was prolonged/difficult) after the first 284 cases. AP ablation procedures were performed by an electrophysiology specialist with considerable experience in general interventional electrocardiology (over 4400 procedures, including approximately 2800 ablations/electrophysi- ological studies performed during the study period). For all electrophysiological studies, a BARD EP system and a mobile C-arm were used.

\section{Statistical analysis}

Categorical variables were expressed as counts and percentages, and continuous variables as means and standard deviations. The association between binary and the continuous variable was estimated using splines in the logistic regression model, and for two continuous variables the spline fit was obtained using the least squares method. A p-value less than 0.05 was considered statistically significant. All statistical analyses were performed using R 3.2.

\section{RESULTS}

We identified 570 consecutive patients scheduled for electrophysiological study/AP ablation, on whom 629 electrophysiological studies and 610 AP ablation procedures were performed; 21 patients had more than one AP and there were 40 re-do procedures including 16 long-term recurrences. One patient died 14 days before scheduled ablation (due to ventricular fibrillation) and was therefore excluded from analysis of procedure success and ablation complications, but he was included in the list of the serious pre-ablation AP-related events. Basic clinical and demographical data, as well ablation strategy/technique, AP localisations, and AP types/variants, some of which were earlier described [10-13], are presented in Table 1.

Overall, 590 APs were successfully ablated, which constituted $96.7 \%$ of all targeted APs; single procedure success was 93.4\%, and average fluoroscopy time was $13.5 \mathrm{~min}$ (142 mGy) (Table 1). Focal cryoablation, stabilising long sheets, and/or $3 \mathrm{D}$ mapping systems were used in $16 \%$ of cases. The learning curve with regard to single procedure success, multiple procedure success, fluoroscopy time reduction, and periprocedural complications are presented in Figure 1. Briefly, there was significantly higher success and less fluoroscopy use with increase in experience $(p=0.049$ and $p<0.0001$, respectively), while periprocedural complications seemed evenly distributed over the years ( $p=0.92)$. The learning was most pronounced in the first 120-140 cases. However, the learning curve fully flattened only after approximately 400 ablations (Fig. 1). The learning curve with regard to the most frequent AP localisation (and considered also as indicative of easier ablation) - i.e. left free wall APs vs. other APs, is presented in Figure 2. With the left free wall APs there was initially a very high success rate, and therefore the learning curve in this subgroup was flat. This was in contrast to the learning curves in the subgroup consisting of the remaining APs: for single procedure a plateau was reached after 150 cases $(p=0.036)$, although for multiple procedure the success rate was rising with growing experience during the included 300 cases $(p=0.028)$. Furthermore, AP localisation significantly influ- 
Table 1. Clinical and electrophysiological characteristics

\begin{tabular}{|c|c|}
\hline Number of patients/APs/ablation procedures [n] & $570 / 630 / 610$ \\
\hline Age [years] & $33 \pm 18.9$ \\
\hline Males & $56.1 \%$ \\
\hline Asymptomatic patients & $16.5 \%$ \\
\hline \multicolumn{2}{|l|}{ AP localisation: } \\
\hline Left free wall & $50.6 \%$ \\
\hline Posteroseptal (right and left) & $19.6 \%$ \\
\hline Right free wall & $10.2 \%$ \\
\hline Midseptal (right and left) & $7.8 \%$ \\
\hline Right anteroseptal & $5.3 \%$ \\
\hline Para-Hisian & $3.1 \%$ \\
\hline Epicardial & $1.8 \%$ \\
\hline Fasciculoventricular (true Mahaim) & $1.3 \%$ \\
\hline In aortomitral continuity & $0.16 \%$ \\
\hline Atrio-Hisian (James) & $0.16 \%$ \\
\hline \multicolumn{2}{|l|}{ AP functional types: } \\
\hline Overt & $67.8 \%$ \\
\hline Concealed & $29.7 \%$ \\
\hline Concealed slow/decremental (Coumel) & $1.1 \%$ \\
\hline Atriofascicular (pseudo-Mahaim) & $1.4 \%$ \\
\hline Single/multiple procedure success rate & $93.4 \% / 96.7 \%$ \\
\hline Mean fluoroscopy time [min] & $13.5 \pm 12.1$ \\
\hline \multicolumn{2}{|l|}{ Use of: } \\
\hline Cryoablation & $4.7 \%$ \\
\hline Stabilising sheets & $6.2 \%$ \\
\hline Three-dimensional system & $5.1 \%$ \\
\hline \multicolumn{2}{|l|}{ Ablation access: } \\
\hline Retrograde aortic & $50.0 \%$ \\
\hline Transseptal puncture & $1.9 \%$ \\
\hline Patent foramen ovale & $2.9 \%$ \\
\hline Right atrium: via superior/inferior vena cava & $42.5 \%$ \\
\hline Coronary sinus & $2.5 \%$ \\
\hline
\end{tabular}

AP - accessory pathways

enced first procedure success rate, with $97 \%$ success rate in left lateral/anterolateral pathways vs. 88-90\% success rate in right free wall and epicardial/septal pathways. However, multiple procedure success rate was lower only for right free wall APs (Fig. 2). The success rate with regard to the precise anatomical AP localisation, presented in Table 2, indicates significantly lower multiple procedure success rate in para-Hisian and right posterolateral APs.

Table 3 lists periprocedural complications and AP-related adverse events observed before ablation. Briefly, there was one $(0.16 \%)$ serious periprocedural complication (a tamponade without further sequelae) and 14 (2.3\%) minor complications; serious pre-ablation AP-related events were observed in 36 (6.3\%) patients, including 12 sudden cardiac arrests (two resulting in serious permanent brain damage and one in death) and 16 pre-cardiac arrest situations (malignant atrial fibrillation).

\section{DISCUSSION Periprocedural complications}

The major finding of this study is that in contrast to the early studies on WPW ablation [5, 14, 15], there were almost no serious complications of AP ablation (major complication rate of $0.2 \%$ - reflecting a single case of tamponade that was managed with straightforward pericardiocentesis during the procedure). It is commonly held that the major complication rate in AP ablation is $2-3 \%$, and that this number should be weighed against the benefits of ablation $[3,5,16]$. However, this view is mostly based on the results of early studies. In these studies, for example, in the Multicentre European Radiofrequency Survey (MERFS), the incidence of complications in relation to the ablation of AP was $4.4 \%$, and this included three deaths [15]. In another study, 500 patients who underwent catheter ablation of an AP complications included $1 \%$ of complete AV blocks, $0.2 \%$ of deaths, and $0.2 \%$ of strokes [5]. However, the recent study by Pappone et al. [17] corroborates our finding of very low rate of serious complications and similar low rate of minor complications during contemporary ablation of APs. In this very large study, there were no deaths, no tamponades, and only a single case of third-degree AV block $(0.08 \%)$; minor complications rate was similar to that of the current study and included pneumothorax in $0.2 \%$, femoral haematomas in $1.9 \%$, fistulas in $0.16 \%$, right bundle branch block in $0.9 \%$; left bundle-branch block in $0.3 \%$, and asymptomatic pericardial effusion in $0.2 \%$. Of note, technological solutions rarely used in the 1990s (focal cryoablation, stabilising long sheets, or 3D mapping systems) were used in the current study during $16 \%$ of ablations, perhaps reducing risk in selected, difficult cases.

\section{Success rate and learning curve for AP ablation} The efficacy of AP ablation of approximately $97 \%$ seen in the current study is similar to that seen in high-volume leading centres, as reported by Nakagawa and Jackman [18] (97.6\%) and Pappone et al. [17] (98.5\%) and slightly higher than in most early studies (86-95\%) [7, 17, 19, 20]. Right free wall AP location was associated with a lower success rate for the first and multiple attempts (Fig. 3). However, the septal pathways success rate was lower for only the first ablation attempt (with the possible exception of para-Hisian pathways).

In the current study the learning curves for both success rate and fluoroscopy time flattened after 400 cases; this is the first report that shows a contemporary single operator learning curve in a large number of patients. Shorter procedure duration (but without data on fluoroscopy time) and higher success rate with experience, was reported by Calkins et al. [10], 

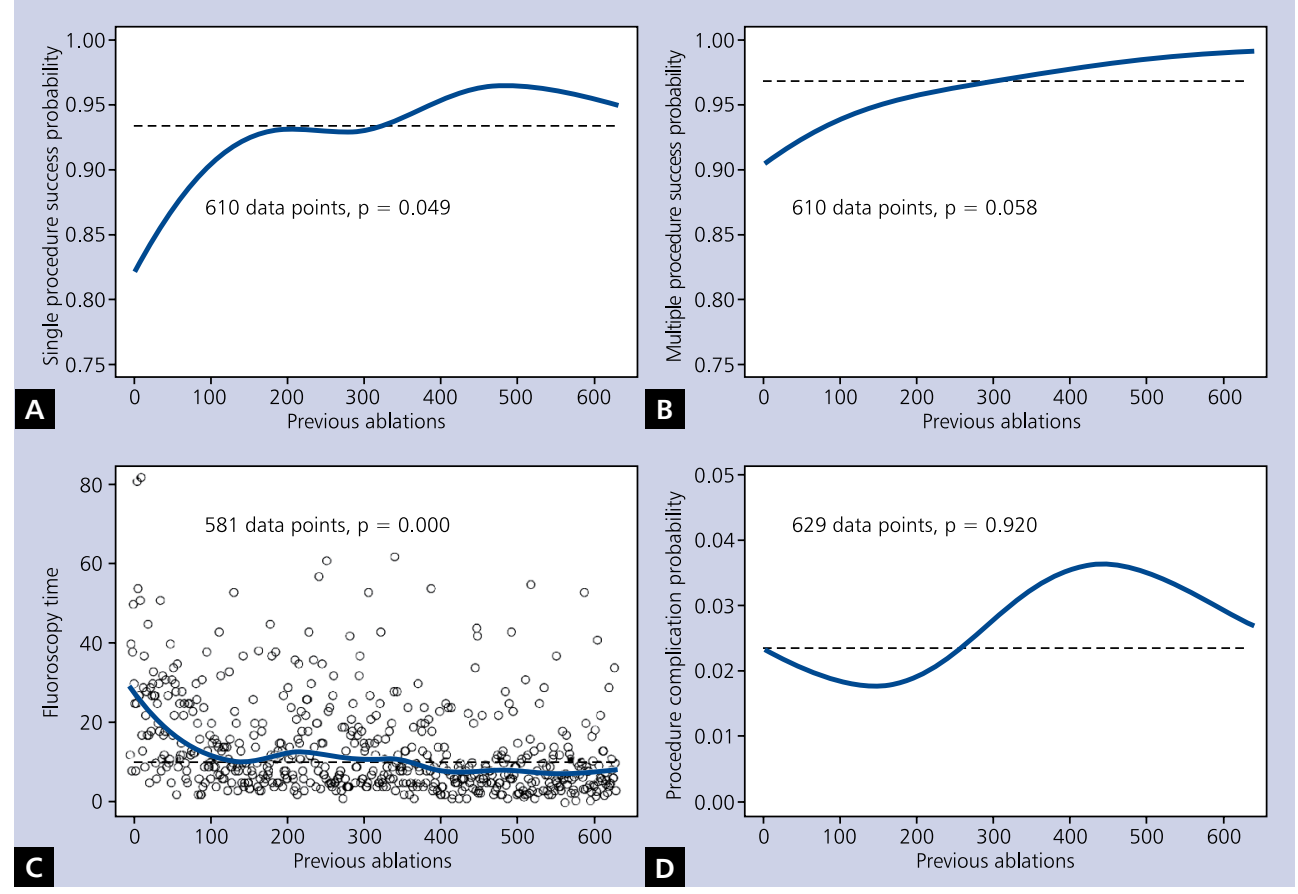

Figure 1. Logistic regression spline fit (solid blue line), overall mean (dashed line); A. Increase in probability of success during the first attempt at accessory pathways (AP) ablation is most obvious for the first 140 cases and reaches a plateau after 400 cases; B. Increase in multiple attempts success probability is continuous, but becomes minimal after 400 cases; C. Decrease in fluoroscopy use is most dramatic during the first 120 cases and reaches a plateau after 400 cases; D. There is no statistical significance for distribution of complications of AP ablation during the 629 procedures spanning a 14-year period
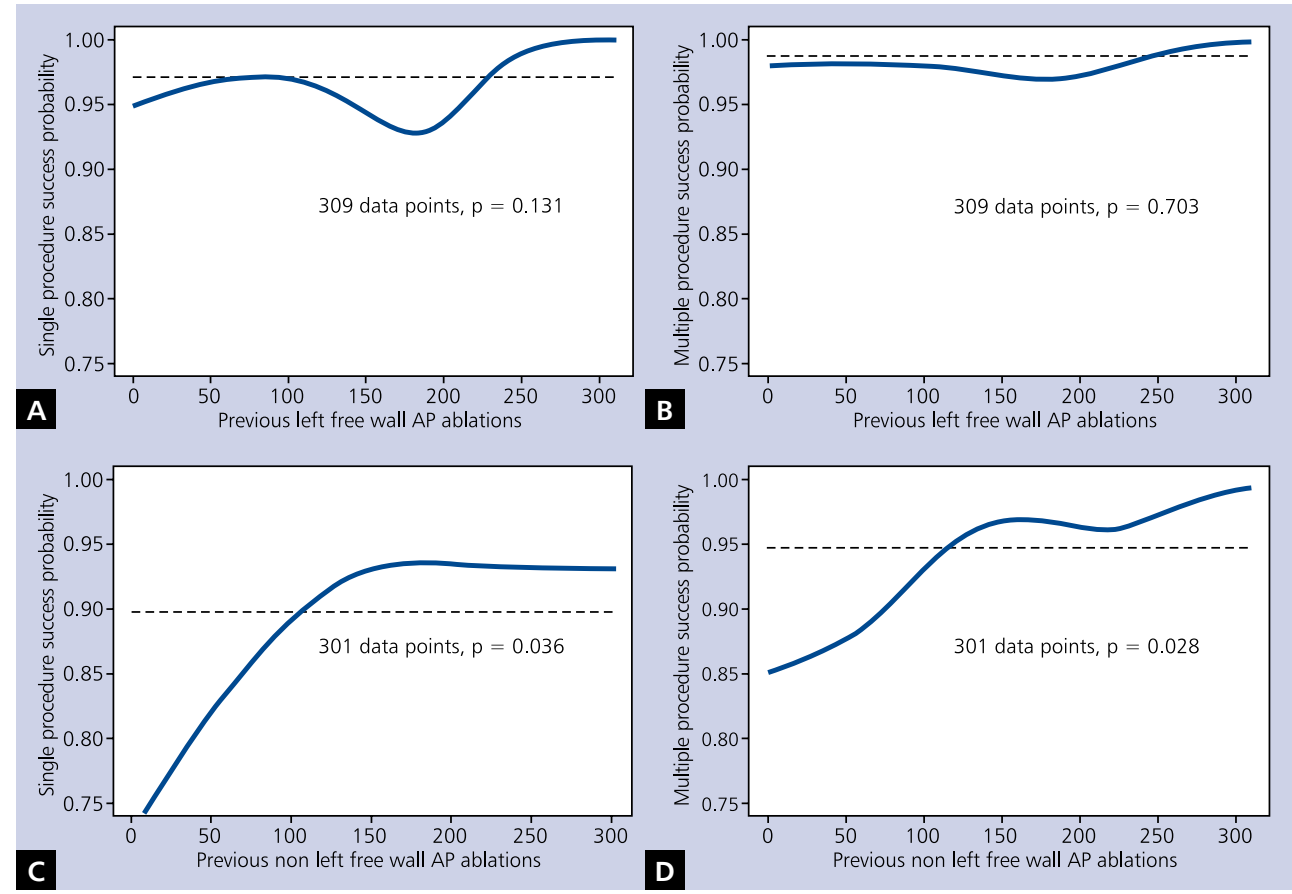

Figure 2. Logistic regression spline fit (solid blue line), overall mean (dashed line); A. Single procedure success rate curve for left free wall accessory pathways (AP) ablation is flat — reflecting the initially very high probability of success; B. Multiple procedure success rate curve for left free wall APs ablation does not change with increase in experience; $C$. Single procedure success rate curve for non left free wall APs ablation reaches a plateau after the first 150 cases; D. Multiple procedure success rate curve for non left free wall APs ablation is rising with experience during the included 300 cases 
Table 2. Impact of accessory pathway (AP) localisation on ablation success

\begin{tabular}{|lcc|}
\hline AP localisation & $\begin{array}{c}\text { First attempt } \\
\text { success } \\
\text { rate }\end{array}$ & $\begin{array}{c}\text { Multiple } \\
\text { attempts } \\
\text { success rate }\end{array}$ \\
\hline Right anterior & $90.0 \%$ & $100.0 \%$ \\
Right anterolateral & $88.9 \%$ & $88.9 \%$ \\
Right lateral & $94.1 \%$ & $100.0 \%$ \\
Right posterolateral & $76.5 \% *$ & $76.5 \% *$ \\
Right posterior & $93.8 \%$ & $93.8 \%$ \\
Right posteroseptal & $92.6 \% *$ & $94.7 \%$ \\
Right midseptal & $100.0 \%$ & $100.0 \%$ \\
Right anteroseptal & $84.4 \% *$ & $93.8 \%$ \\
Para-Hisian & $83.3 \% *$ & $88.9 \% * *$ \\
Epicardial & $66.7 \% *$ & $91.7 \%$ \\
Left midseptal & $71.4 \% *$ & $100.0 \%$ \\
Left posteroseptal & $92.6 \%$ & $100.0 \%$ \\
Left posterior & $93.2 \% *$ & $98.3 \%$ \\
Left posterolateral & $95.7 \%$ & $100.0 \%$ \\
Left lateral/anterolateral & $98.5 \%$ & $98.5 \%$ \\
\hline
\end{tabular}

${ }^{*} p<0.05$ vs. left lateral/anterolateral; ${ }^{* *} p=0.054$ vs. left lateral/ /anterolateral

Table 3. Ablation complications and serious events related to untreated accessory pathway (AP)

\begin{tabular}{|lc|}
\hline Major periprocedural complications & \\
Death & $0(0 \%)$ \\
Stroke & $0(0 \%)$ \\
II/III degree AV block or pacemaker implantation & $0(0 \%)$ \\
Tamponade & $1(0.16 \%)$ \\
Need for surgical intervention & $0(0 \%)$ \\
Minor periprocedural complications & \\
I degree AV block & $1(0.16 \%)$ \\
RBBB & $3(0.48 \%)$ \\
LBBB & $1(0.16 \%)$ \\
Pericardial fluid & $1(0.16 \%)$ \\
Pneumothorax & $2(0.32 \%)$ \\
Groin haematoma & $3(0.48 \%)$ \\
Arteriovenous fistula/femoral artery aneurysm & $1(0.16 \%)$ \\
Deep vein thrombosis & $2(0.32 \%)$ \\
Aortic valve insufficiency (I degree) & $1(0.16 \%)$ \\
Serious events related to untreated APs & \\
Sudden cardiac arrest (ventricular fibrillation) & $12(3.1 \%)^{*}$ \\
Malignant AF/near cardiac arrest & $16(4.1 \%)^{*}$ \\
Other (syncope, heart failure, etc.) & $9(1.6 \%)$ \\
\hline
\end{tabular}

${ }^{*}$ Calculated for patients with overt AP $(\mathrm{n}=386)$; " resulting in permanent serious brain damage in two and death in one (0.8\%); $A F-$ atrial fibrillation; AV - atrioventricular block; LBBB — left bundle branch block; RBBB — right bundle branch block

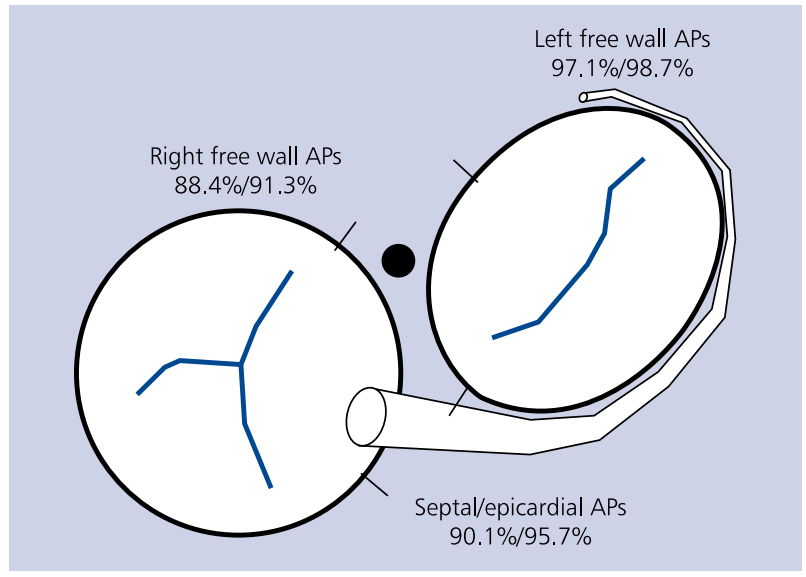

Figure 3. Single procedure ablation success rate for right free wall accessory pathways (AP) and septal/epicardial APs was significantly lower than that of left free wall pathways ( $p<0.01)$. Multiple attempts success rate was lower only for right free wall APs $(p<0.01)$

although these data came from a group of several operators. Danford et al. [14] reported the learning curve for AP ablation in children/adolescents. However, the data were also from the early 1990s and fluoroscopy times were several times longer (72-36 min) than in the current study (13.5 min).

Data concerning learning curve and achievable low complication rates when procedures are performed by an experienced operator/centre might be more important nowadays because AP ablation is becoming a less common procedure, with most electrophysiologists/centres busy with atrial fibrillation and ventricular tachycardia ablation.

\section{Limitations of the study}

Due to the retrospective nature of the study, minor complications might have been underreported and therefore underestimated, especially local access-related vascular complications like haematomas, arteriovenous fistulas, and pseudoaneurysms.

Acute and short-term success investigated in the current study does not equal long-term success, due to a known small recurrence rate in AP conduction after initially successful ablation. We did not aim at analysing the long-term success rate due to lack of rigorous long-term follow-up in our cohort. Nevertheless, long-term success can be approximated as all patients were strongly recommended to have an ECG after two to three months and to visit our outpatient department in the case of overt pre-excitation in the ECG or symptom recurrence. Probably the 16 cases reported by us represent the majority of patients with long-term recurrences. All APs with long-term recurrence of conduction were re-ablated successfully and without complications.

\section{CONCLUSIONS}

The current study suggests that in the modern era AP ablation can be safer than it was in the first two decades after the 
introduction of catheter ablation of APs. Moreover, this largest single-operator data on AP ablation outcomes indicates that experience builds up over several hundred ablation cases. These results, viewed in the perspective of the rare yet potentially devastating consequences of untreated AP, suggest that in experienced centres there should be less reluctance to routinely perform electrophysiological study in asymptomatic/mildly symptomatic patients with pre-excitation.

\section{Conflict of interest: none declared}

\section{References}

1. Scheinman MM, Morady F, Hess DS, et al. Catheter-induced ablation of the atrioventricular junction to control refractory supraventricular arrhythmias. JAMA. 1982; 248(7): 851-855, indexed in Pubmed: 7097946.

2. Borggrefe M, Budde T, Podczeck A, et al. High frequency alternating current ablation of an accessory pathway in humans. J Am Coll Cardiol. 1987; 10(3): 576-582, indexed in Pubmed: 3624664.

3. Page RL, Joglar JA, Caldwell MA, et al. 2015 ACC/AHA/HRS Guideline for the Management of Adult Patients With Supraventricular Tachycardia: Executive Summary: A Report of the American College of Cardiology/American Heart Association Task Force on Clinical Practice Guidelines and the Heart Rhythm Society. J Am Coll Cardiol. 2016; 67(13): 1575-1623, doi: 10.1016/j.jacc.2015.09.019, indexed in Pubmed: 26409258.

4. Skanes AC, Obeyesekere M, Klein GJ. Electrophysiology testing and catheter ablation are helpful when evaluating asymptomatic patients with Wolff-Parkinson-White pattern: the con perspective. Card Electrophysiol Clin. 2015; 7(3): 377-383, doi: 10.1016/j. ccep.2015.05.002, indexed in Pubmed: 26304516.

5. Calkins H, Yong P, Miller JM, et al. Catheter ablation of accessory pathways, atrioventricular nodal reentrant tachycardia, and the atrioventricular junction: final results of a prospective, multicenter clinical trial. The Atakr Multicenter Investigators Group. Circulation. 1999; 99(2): 262-270, indexed in Pubmed: 9892593.

6. Kuck K, Schluter M, Geiger M, et al. Radiofrequency current catheter ablation of accessory atrioventricular pathways. Lancet. 1991; 337(8757): 1557-1561, doi: 10.1016/0140-6736(91)93258-b.

7. Jackman WM, Wang XZ, Friday KJ, et al. Catheter ablation of accessory atrioventricular pathways (Wolff-Parkinson-White syndrome) by radiofrequency current. N Engl J Med. 1991; 324(23): 1605-1611, doi: 10.1056/NEJM199106063242301, indexed in Pubmed: 2030716.

8. Calkins H, Sousa J, El-Atassi R, et al. Diagnosis and cure of the Wolff-Parkinson-White syndrome or paroxysmal supraventricular tachycardias during a single electrophysiologic test. N Engl J Med. 1991; 324(23): 1612-1618, doi: 10.1056/nejm199106063242302.

9. Kay GN, Epstein AE, Dailey SM, et al. Role of radiofrequency ablation in the management of supraventricular arrhythmias: experience in 760 consecutive patients. J Cardiovasc Electrophysiol. 1993; 4(4): 371-389, indexed in Pubmed: 8269306.
10. Calkins H, el-Atassi R, Kalbfleisch SJ, et al. Effect of operator experience on outcome of radiofrequency catheter ablation of accessory pathways. Am J Cardiol. 1993; 71(12): 1104-1105, indexed in Pubmed: 8475877.

11. Jastrzebski M, Hart R, Czarnecka D. Wide QRS Complex Tachycardia in a Patient With Complete Heart Block: What Is the Mechanism? J Cardiovasc Electrophysiol. 2016; 27(6): 765-767, doi: 10.1111/jce.12890, indexed in Pubmed: 26639166.

12. Jastrzebski M, Pitak M, Rudzinski A, et al. Wide QRS complex tachycardia in a patient with concealed accessory pathway: what is the mechanism? J Cardiovasc Electrophysiol. 2016; 27(9): 1121-1123, doi: 10.1111/jce.12992, indexed in Pubmed: 27094587.

13. Jastrzebski M. An unusual case of preexcitation: where is the accessory pathway? J Cardiovasc Electrophysiol. 2016; 27(2): 236-238, doi: 10.1111/jce.12769, indexed in Pubmed: 26235091.

14. Danford DA, Kugler JD, Deal B, et al. The learning curve for radiofrequency ablation of tachyarrhythmias in pediatric patients. Participating members of the Pediatric Electrophysiology Society. Am J Cardiol. 1995; 75(8): 587-590, indexed in Pubmed: 7887383.

15. Hindricks G. The Multicentre European Radiofrequency Survey (MERFS): complications of radiofrequency catheter ablation of arrhythmias. The Multicentre European Radiofrequency Survey (MERFS) investigators of the Working Group on Arrhythmias of the European Society of Cardiology. Eur Heart J. 1993; 14(12): 1644-1653, indexed in Pubmed: 8131762.

16. Blomstrom-Lundqvist C, Scheinman MM, Aliot EM, et al. ACC/AHA/ESC guidelines for the management of patients with supraventricular arrhythmias-executive summary A Report of the American College of Cardiology/American HeartAssociation Task Force on Practice Guidelines and the European Society of Cardiology Committee for Practice Guidelines(Writing Committee to Develop Guidelines for the Management of Patients With Supraventricular Arrhythmias)Developed in collaboration with NASPE-Heart Rhythm Society. Eur Heart J. 2003; 24(20): 1857-1897, doi: 10.1016/j.ehj.2003.08.002.

17. Pappone C, Vicedomini G, Manguso F, et al. Wolff-Parkinson-White syndrome in the era of catheter ablation: insights from a registry study of 2169 patients. Circulation. 2014; 130(10): 811-819, doi: 10.1161/CIRCULATIONAHA.114.011154, indexed in Pubmed: 25052405.

18. Nakagawa H, Jackman WM. Catheter ablation of paroxysmal supraventricular tachycardia. Circulation. 2017; 116(21): 2465-2478, doi: 10.1161/CIRCULAATIONAHA.106.655746, indexed in Pubmed: 18025404.

19. Calkins H, Langberg J, Sousa J, et al. Radiofrequency catheter ablation of accessory atrioventricular connections in 250 patients. Abbreviated therapeutic approach to Wolff-Parkinson-White syndrome. Circulation. 1992; 85(4): 1337-1346, indexed in Pubmed: 1555278.

20. Schlüter M, Geiger M, Siebels J, et al. Catheter ablation using radiofrequency current to cure symptomatic patients with tachyarrhythmias related to an accessory atrioventricular pathway. Circulation. 1991; 84(4): 1644-1661, indexed in Pubmed: 1914104.

Cite this article as: Jastrzębski M, Moskal P, Pitak M, et al. Contemporary outcomes of catheter ablation of accessory pathways: complications and learning curve. Kardiol Pol. 2017; 75(8): 804-810, doi: 10.5603/KP. 2017.0153. 


\title{
Współczesne wyniki ablacji szlaków dodatkowych: powikłania i krzywa uczenia się
}

\author{
Marek Jastrzębski ${ }^{1}$, Paweł Moskal ${ }^{1}$, Maciej Pitak², Kamil Fijorek ${ }^{3}$, Andrzej Rudziński², Danuta Czarnecka1 \\ II Klinika Kardiologii, Elektrokardiologii Interwencyjnej oraz Nadciśnienia Tętniczego, Uniwersytet Jagielloński, Collegium Medicum, Kraków \\ ${ }^{2}$ Klinika Kardiologii Dziecięcej, Instytut Pediatrii, Uniwersytet Jagielloński, Collegium Medicum, Kraków \\ ${ }^{3}$ Wydział Statystyki, Uniwersytet Ekonomiczny, Kraków
}

\section{Streszczenie}

Wstęp i cel: Celem badania była ocena współczesnych wyników ablacji szlaków dodatkowych w dużej grupie chorych, ukierunkowana na analizę powikłań oraz krzywej uczenia się.

Metody: Wykonano retrospektywne badanie kohortowe obejmujące kolejne zabiegi ablacji szlaku dodatkowego przeprowadzone w trzech ośrodkach przez tego samego operatora. Przeanalizowano 629 badań elektrofizjologicznych i 610 ablacji przeprowadzonych u 570 pacjentów (wiek $33 \pm 18,9$ roku).

Wyniki: Wystąpiło jedno (0,16\%) poważne powikłanie i 14 (2.3\%) lżejszych powikłań. 590 szlaków poddano skutecznej ablacji: odsetek udanych zabiegów przy jednej sesji i kilku sesjach ablacyjnych wyniósł odpowiednio 93,4\% i 96,7\%; średni czas zastosowania promieniowania rentgenowskiego (RTG) wyniósł 13,5 min. Wraz z doświadczeniem w sposób istotny wzrósł odsetek udanych zabiegów, a obniżył się czas promieniowania RTG, natomiast powikłania były równomiernie rozłożone w czasie. Efekt uczenia był najwyraźniejszy w ciągu pierwszych 120 przypadków, jednak pełne wypłaszczenie krzywej uczenia się nastąpiło dopiero po 400 ablacjach.

Wnioski: Wyniki badania sugerują, że w XXI wieku ablacja szlaków dodatkowych jest bezpieczniejsza niż w pierwszych dwóch dekadach od wprowadzenia przezskórnych ablacji szlaków dodatkowych. Wydaje się, że w doświadczonych ośrodkach zasadny jest niższy próg decyzyjny przy kierowaniu bezobjawowych chorych z preekscytacją na badanie elektrofizjologiczne. Słowa kluczowe: szlak dodatkowy, preekscytacja, ablacja, powikłania, krzywa uczenia się

Kardiol Pol 2017; 75, 8: 804-810 